\title{
Use and User Satisfaction with Library Services and Resources at the Main Library of the General Sir John Kotelawala Defence University, Sri Lanka
}

\author{
T.C. Ranawella ${ }^{1}$ and M.P. Rajapaksha ${ }^{2}$
}

\begin{abstract}
The main library of the General Sir John Kotelawela Defence University conducted a survey of the first and third-year undergraduates of the Faculty of Engineering and Faculty of Management, Social Sciences and Humanities, to investigate the use and user satisfaction on library services and resources. The study employed the 455 structured questionnaires to the whole population of undergraduates as the main tool for collecting data. Further, various registers were used to count the number of users. Collected data were analyzed using SPSS Version 20. The major findings of the study revealed that the respondents were satisfied with the library resources and services of the library as a whole. Also, the study found that many of the respondents visit the library for more than one reason, whereas the majority of the respondents visit the library for accessing past papers. Other findings show that the largest proportion of the respondents visit the library once a week. As for resources, the textbooks were ranked first, followed by the newspapers/magazine, and reference sources. The less frequently used resources are CD/DVD/VCD, online journals, databases, and library web links. To meet undergraduate information requirements and make them aware of the available resources and services, it is recommended to conduct information literacy programs as well as awareness programs at regular intervals.
\end{abstract}

Keywords: Library Resources, Library Services, User Satisfaction, Library Facilities, Information Literacy, Library Skills.

\footnotetext{
${ }^{1}$ Acting Librarian, General Sri John Kotelawala Defence University, Email: thanuja@kdu.ac.lk

${ }^{2}$ Senior Assistant Librarian, General Sri John Kotelawala Defence University, Email: primali83rajapakshaa@kdu.ac.lk
}

(iD http://orcid.org/0000-0002-5025-8187 (c) (O) This work is licensed under a Creative Commons Attribution-Share A like
4.0 International License. 


\section{Introduction}

University libraries in the world are serving academic programs of the university by providing relevant information and they support the university curriculum as well as research needs of the faculties and students of the university and advance their knowledge. According to Adeniran (2011), the library plays a key role in the nation building process. Therefore, the library of a university is an essential part of the higher education system which has traditionally been seen and recognized as the "heart" of the learning community of that university.

Normally, university libraries are devoted to providing an excellent service for users. Each year new students enter the university with different library usage patterns and information-gathering skills. At the same time, people have different perceptions and expectations of service from academic libraries. This will depend on the size and the collection of the library, the adequacy and accuracy of the organization of its collection, the usefulness of its catalogues and other finding tools in providing access to its collection, the ability and the cooperation of the library staff, and how the library maximizes their exposure to its resources and to other library services. In this sense, systematic evaluation of user needs against existing resources and services of the library is very much important for the continuous upgrading of the services provided by the library. According to Patrick, Aghojare and Ferdinand (2015) assessment of library services is considered as a management tool which is useful to determine how library serves to determine the needs of its users. Further, they said that assessment could be used to identify the failures and the limitations of service and it helps to put forward recommendations to improve such service.

\section{Background to Environment of Study}

The General Sir John Kotelawela Defence University (KDU) is one of the prestigious military universities in South Asia. It is a fully-fledged university with nine faculties and caters to ever growing demands of higher education in all scopes even though the prime focus of the university is on defence. The KDU library was established in 1980 to provide information resources and services to meet users' information needs and to support research of the university staff and students. The KDU library network consists of two other 
branch libraries, including Medical and Allied Health Sciences libraries. Collection related to Social Sciences, Management, Engineering and other special collections, such as Military Collection, Sri Lanka Collection, Donor's Collection, Journal Collection, Newspaper Collection, general reading books and other recreational collection is organized in the main library. At present, it possesses more than 25500 volumes and serves approximately 5000 undergraduates, postgraduates, and about 900 faculty staff. The library is also equipped with Wi-Fi internet facilities, thus enabling students to access the OPAC through the library web page.

Even though KDU library provides a range of library services and facilities to its users, it is worthwhile to study how its users get the maximum benefit of the library services and their satisfaction level. This will provide proper guidance to the library management on how to develop and expand its services effectively and efficiently. Therefore, this study aims to examine the use and user satisfaction with library resources and services at the main library of the General Sir John Kotelawala Defence University.

\section{Literature Review}

Vast amounts of literature are available on assessing user satisfaction in library resources and services belonging to various user groups, universities, educational levels as well as the impact of performances in libraries. Hence, it is important to review different types of studies, methodologies, findings and recommendations.

To determine clients' satisfaction with library services, infrastructure/place/space and collection/information provided by an academic library at Federal University of Petroleum Resources Library, Patrick, Aghojare and Ferdinand (2015) conducted a survey. The authors revealed that the respondents were highly satisfied with the library services and collection as a whole. He identified that most of the respondents visited the library due to the availability of internet connectivity. Respondents were also suggested to increase the internet bandwidth and the library opening hours. Adeniran (2011) examined the relation between service quality and users' satisfaction at Redeemer's University and revealed that users were 
satisfied with the services of its' library and students of the College of Management Sciences had the highest frequency of use.

While identifying user needs, Gunasekera (2010), assessed user satisfaction with current information services and resources. From the study, the author found that the students were satisfied with available resources, facilities and services of the library. Moreover, the author found that resources and services of the library were being underutilized by students. At the same time, to promote the use of electronic information resources and awareness of the users, the author recommended to conducting an information literacy program.

Chandrasekar and Murugathas (2013) assessed user satisfaction with library services by undergraduate biology students and found that even though the undergraduates were overall satisfied with the collection, reading materials were insufficient. Therefore authors highly recommended improving the book collection with its latest edition. Further, the study emphasized the need for improving library services including Inter Library Loan service, photocopying service, selective dissemination of information and current awareness service.

Olanlokum (1982) identified the reasons for students to use the library for research, class work, leisure, discussions, and various other purposes. Ajayi (1993) identified that students who did not know the value of resources and services rendered by the library, visited the library only to read for examinations. This was confirmed by the findings revealed in the study done by Yusuf and Iwu (2010) for $88 \%$ of the study sample visited the library to read for examinations purposes. Most of the faculty members visited the library to read journals, both online and offline or print. Students used Online Public Access Catalogue (OPAC) more than the faculty members. The authors have recommended that faculty members should give reading assignments for the students, not just for examination purposes but for students to access journals and other resources in the library. To showcase the various resources available, the authors also recommended that the library should organize a "library week" each semester. 
Seneviratne (2006), measuring user satisfaction at the PGIM branch library at Peradeniya and found that most of the respondents were somewhat or very satisfied with overall library services and staff performance. Further the study noted that respondents were moderately satisfied with the print collection and least satisfied with space and ventilation. Finally, the author pointed out the necessity of related studies in regular intervals.

Ajibero (1998) revealed that user expectation level of the students in Nigerian university libraries is at a minimal level. Due to that, they were not aware of the way to use the library and the relationship between their studies and the library.

Sahak, and Saad (2011) investigated the usage of library resources, services and facilities among the first and third-year medical students in the Faculty of Medicine and Health Sciences (FPSK), University Putra Malaysia (UPM). The Authors identified that all respondents, visited the library to study and to use the internet. Further, it was identified that they preferred to use the library to do their assignments, discussions with friends and for leisure reading. Moreover, it was revealed that the internet, newspapers, and library website were the most used resources, while the use of OPAC, project papers, EZ-Proxy, full-text journals, encyclopedia, thesis and statistical reports were identified as being used at bay in terms of frequency of usage. As per the results, the most demanded facilities were access to computers, followed by the reading area, discussion room, and prayer room, printing and photocopying facilities while self-check machines were also in demand by students. A similar study was done by Majid and Ai (2002) at the Nanyang Technological University, Singapore found that printed materials were the most preferred information format among students. They found that the use of databases and electronic journals was quite low among the Computer Engineering students and recommended promotional campaigns for introducing electronic information sources to the library users. Further, Omehia and Itohowo (2008) pointed out that the use of library services by undergraduates differ on their academic discipline (science, social science and humanities, and arts). The same findings were corroborated with what was reported by Sharma (1988), Goje (1995), and Leckie and Fullerton (1999). 


\section{The Problem of Statement}

Doris and Adesina (2013) said that libraries strive hard to ensure that their services are effective, but it is not unlikely that users, especially undergraduates have a different view of library services. Likewise, the purpose of the KDU library is also futile if users are not satisfied with the resources and services provides by the library. In order to develop an effective collection and services, it is necessary for libraries to carry out an occasional assessment of service effectiveness and satisfaction with library services from the user perspective which can be done by conducting user surveys. Therefore, this study is set to find out the impact of library services and resources and identify whether the users of the KDU library are satisfied with the current resources and services rendered by the library as well as to identify library user needs.

\section{Objectives of the Study}

The main objectives of the study are as follows:

- To investigate the purpose and the frequency of library visits by undergraduates

- To study the use of library resources and facilities currently rendered by the library

- To determine the level of satisfaction of users towards library resources and services

\section{Methodology}

The methodology consisted of the survey method and a closed ended questionnaire was designed and incorporated to collect data for the study.

The questionnaire was distributed among a sample of 576 first year and third-year undergraduates from the Faculty of Engineering and Faculty of Management, Social Sciences and Humanities at the General Sir John Kotelawala Defence University. Out of 576, 455 of the questionnaires were duly completed and were incorporated in the study. The sample was stratified according to the actual student population of the two Faculties, but the respondents were selected among the first year and third year undergraduates of the two faculties, including officer cadets and day scholars. A sample of 360 Engineering undergraduates and 216 Social 
Sciences undergraduates were taken as the sample for this study. The research instrument of this study is a structured questionnaire and it was administrated to the undergraduates during their lectures or just before a lecture and collected at the end of the lecture.

The second year undergraduates and final year undergraduates were excluded due to their absence from the university since they had been sent to the industrial and relevant military training at the time of the present study. Faculty of Medicine and Faculty of Allied Health Sciences were also excluded due to time constrains of this study.

The questionnaire was in four parts. Part A exposed demographic data, such as, student category, gender, student intake and a stream of study. Part B was designed to gather information about their library visits, such as to identify the frequency of visits as well as the reason for their visits. Part $\mathrm{C}$ was used to expose information on respondents' usage of library resources and questions relevant to library services and facilities were given in part D of the questionnaire. The data were analyzed using SPSS version 20. The results of the analyses were represented in the forms of tables and charts.

\section{Results and Discussion}

Table 1: Response rate by selected sample (As per the faculty and academic year)

\begin{tabular}{|l|c|c|c|c|c|}
\hline \multirow{2}{*}{$\begin{array}{l}\text { Academic } \\
\text { year }\end{array}$} & \multicolumn{5}{|c|}{ Faculty } \\
\cline { 2 - 6 } & \multicolumn{2}{|c|}{ Faculty of Engineering } & $\begin{array}{c}\text { Faculty of Social Sciences, } \\
\text { Humanities and } \\
\text { Management }\end{array}$ & $\begin{array}{c}\text { Total } \\
\text { number of } \\
\text { responses } \\
\text { received } \\
(\mathbf{n = 4 5 5})\end{array}$ \\
\hline & $\begin{array}{c}\text { Questionnaire } \\
\text { distributed }\end{array}$ & $\begin{array}{c}\text { Response } \\
\text { received }\end{array}$ & $\begin{array}{c}\text { Questionnaire } \\
\text { distributed }\end{array}$ & $\begin{array}{c}\text { Response } \\
\text { received }\end{array}$ & \\
\hline $1^{\text {st }}$ year & 209 & 171 & 134 & 81 & 252 \\
\hline $2^{\text {nd }}$ year & 151 & 140 & 82 & 63 & 203 \\
\hline Total & 360 & $\begin{array}{c}\mathbf{3 1 1} \\
\mathbf{( 6 8 . 3 5 \% )}\end{array}$ & 216 & $\begin{array}{c}\mathbf{1 4 4} \\
\mathbf{( 3 1 . 6 4 \% )}\end{array}$ & $\begin{array}{c}\mathbf{4 5 5} \\
\mathbf{( 7 9 \% )}\end{array}$ \\
\hline
\end{tabular}

Table 1 demonstrates the total responses of the students and it was $79 \%$. Out of that, $311(68.35 \%)$ respondents were from the Faculty of Engineering, 144 
(31.64\%) were from the Faculty of Management, Social Sciences and Humanities. This indicated that the majority of the respondents were from the Faculty of Engineering.

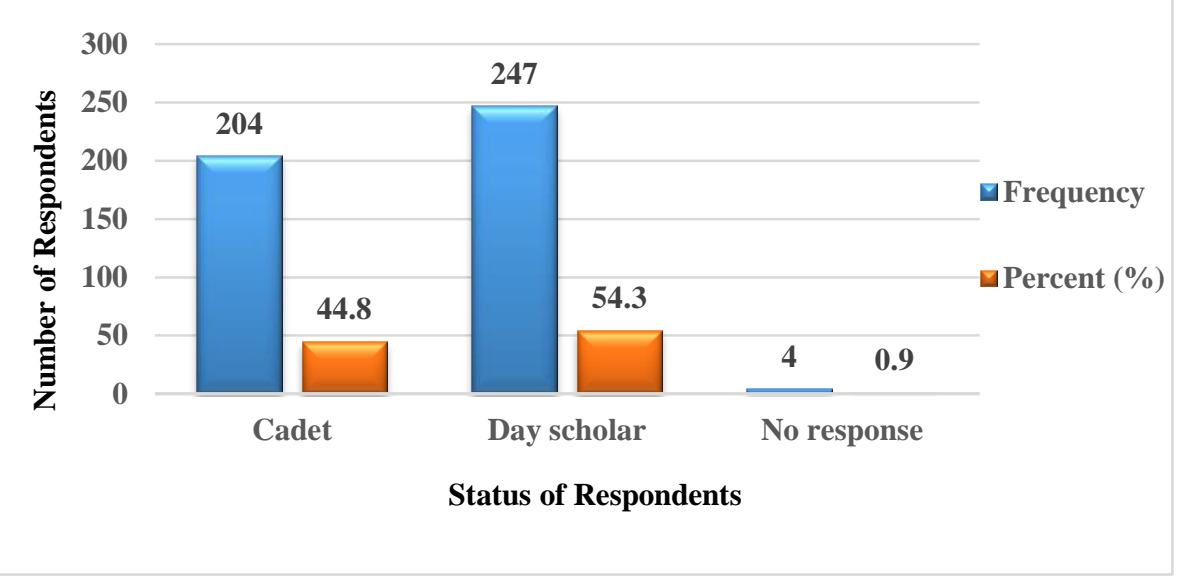

\section{Figure 1: Distribution of Respondents by Status}

Figure 1 shows the status of the target population. Out of the 455 (100\%) respondents, it reveals that $204(44.8 \%)$ were cadets, 247 (54.3\%) were day scholars and remaining $4(0.9 \%)$ respondents did not indicate the status. This represents the status of students involved in the study which out of the majority of them were day scholars.

As per Figure 2, it was revealed that $376(82.6 \%)$ of respondents were male, $75(16.5 \%)$ respondents were female while $4(0.9 \%)$ of respondents did not mention their gender. This represents the gender distribution of students involved in the study. This reveals that the majority of the respondents were male. 


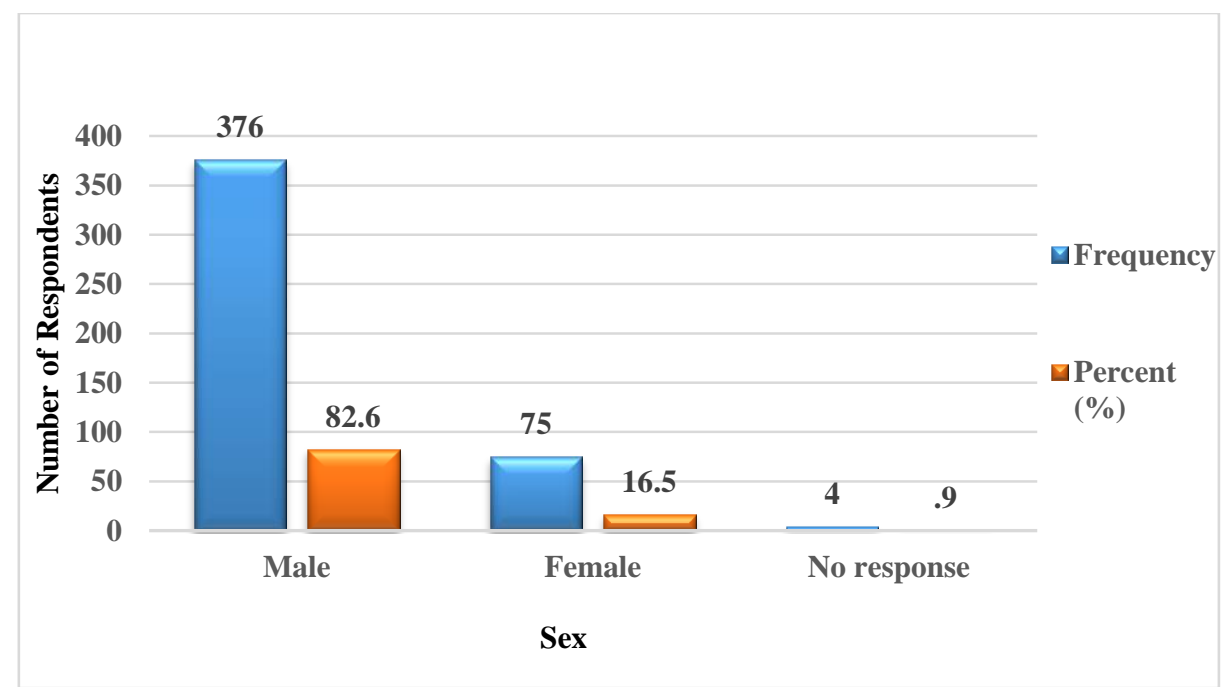

Figure 2: Distribution of Respondents by Sex

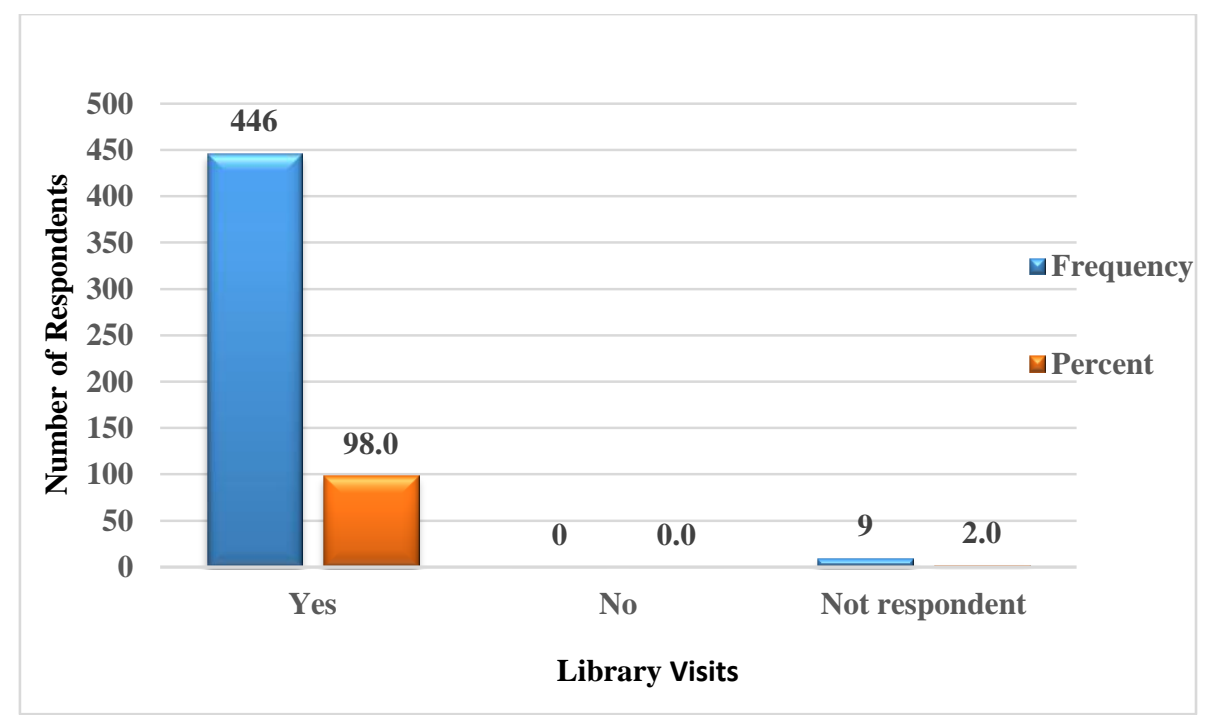

Figure 3: Distribution of Respondents by Library Visits

As observed in Figure 3, the majority (98\%) of the respondents visit the library while a quite small percentage $(2.0 \%)$ of the respondents did not mention their response regarding the library visit. This indicates that the majority who visit the library is undergraduates. 


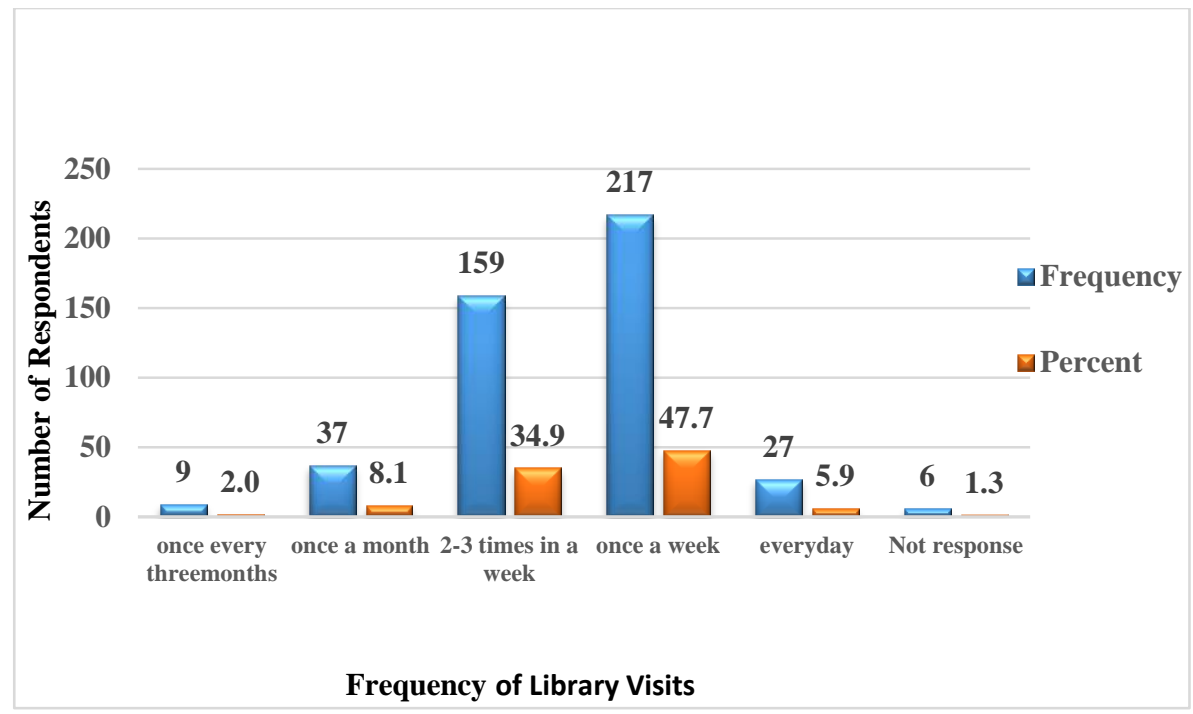

\section{Figure 4: Distribution of Respondents by Frequency of Library Visits}

When the participants were asked to indicate how often they used the library, the majority, $217(47.75 \%)$ of the respondents mentioned that they used the library once a week, while 159 (34.9\%) used 2-3 times a week, 37 (8.1\%) used once a month, 27 (5.9\%) used every day, 9 (2.0\%) used the library once every three months, whereas $6(1.3 \%)$ of the respondents did not respond in this regard ( Figure 4).

It is evident from Figure 5 that the majority, 262 (57.6\%) of the respondents use the library during the normal time schedule $(8.00 \mathrm{am}-2.30 \mathrm{pm})$ which allocated in their timetable for library use. In addition, $89(19.6 \%)$ of the respondents come to the library between $6.00 \mathrm{pm}$ and $9.00 \mathrm{pm}$, while 56 $(12.3 \%)$ come between $2.30 \mathrm{pm}$ and $4.00 \mathrm{pm}$. Very few respondents 38 $(8.4 \%)$ visit the library between $4.00 \mathrm{pm}$ and $6.00 \mathrm{pm}$. Further, it is observed that quite a few respondents $10(2.2 \%)$ did not mention the library visiting time. 


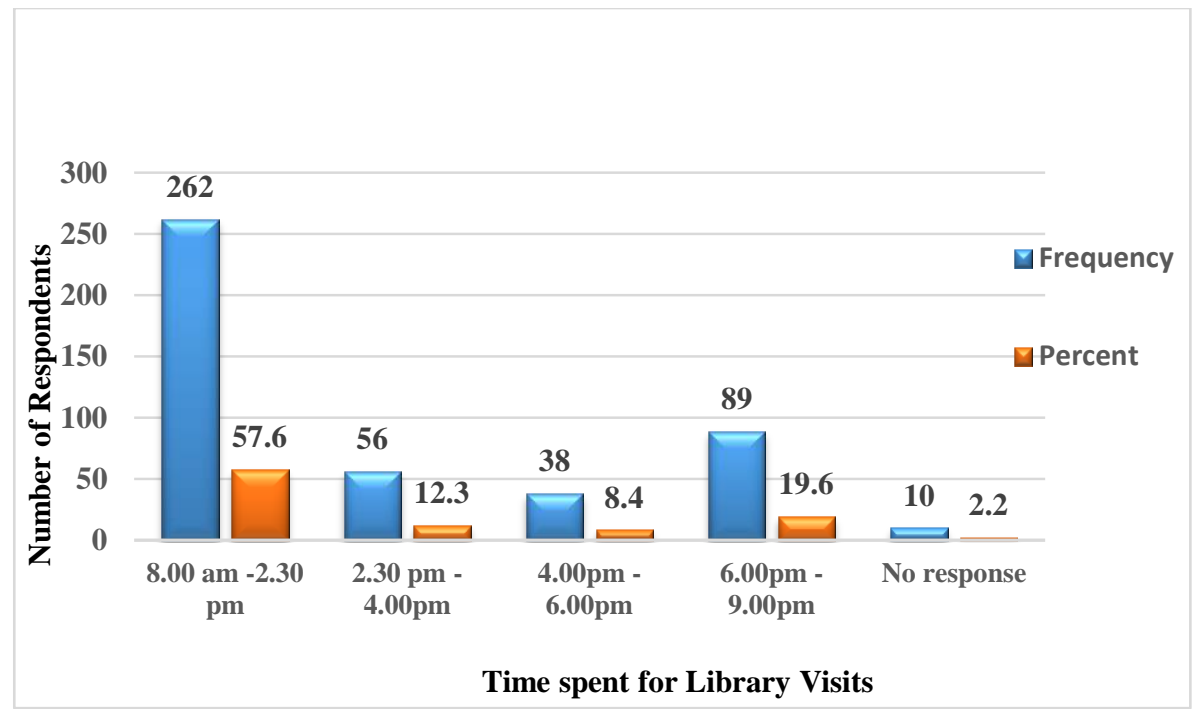

Figure 5: Distribution of Respondents by Time Spent for Library Visits

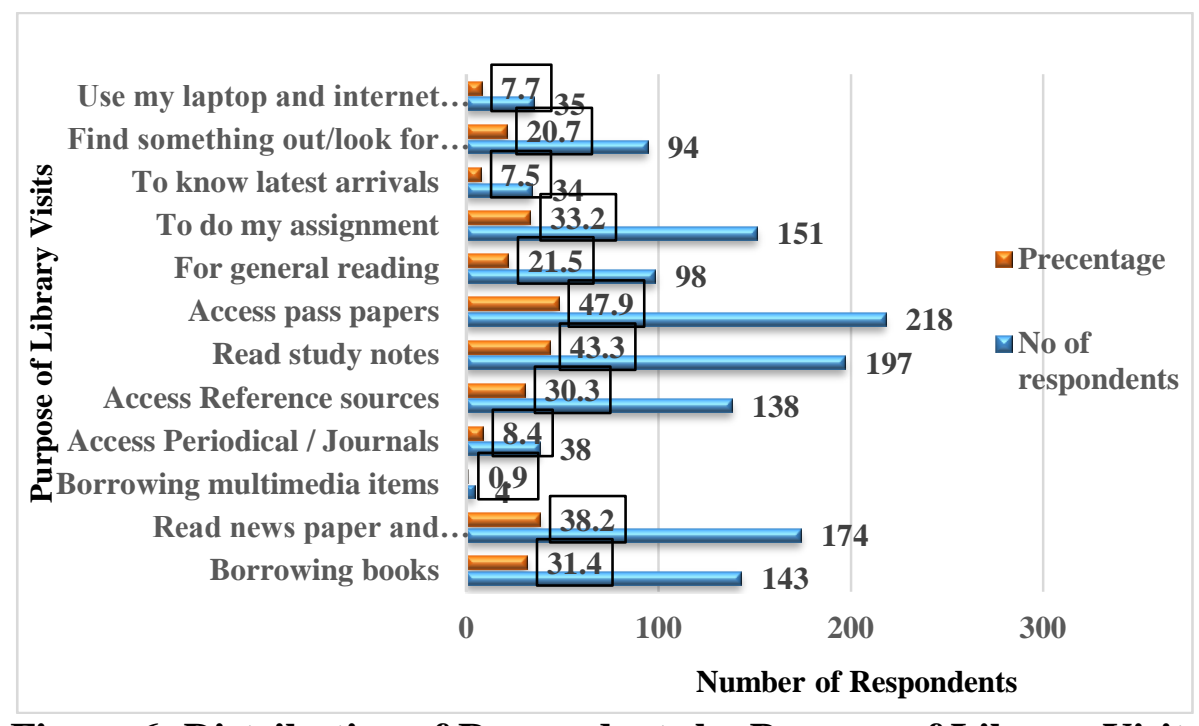

Figure 6: Distribution of Respondents by Purpose of Library Visits

Figure 6 shows that the majority 218 (47.9\%) of the respondents visit the library for the purpose of accessing past papers, 197 (43.3\%) respondents visit in order to read their study notes. $174(38.2 \%)$ of the respondents visit the library to read newspapers and magazines. In addition, $151(33.2 \%)$ and $143(31.4 \%)$ of the respondents visit the library to do their assignments and to borrow books respectively. $138(30.3 \%)$ of the respondents visit the 
library to access reference sources. 98 (21.5\%) and $94(20.7 \%)$ of the respondents visit the library for general reading purpose and to look for information, respectively. Moreover, very less amount of respondents (8.4\%). visit the library to access periodicals/journals, $35(7.7 \%)$ and 34 (7.5\%) respondents visits the library to use the internet facility and to know the new arrivals, respectively. It is observed from Figure 6 that borrowing multimedia items is the least priority $(0.9 \%)$ for the purpose of the library visit by the respondents.

\section{Library Resources}

Table 2 demonstrates the use of library resources by the respondents.

Table 2: Usage of Resources

\begin{tabular}{|c|l|r|r|r|c|}
\hline S/No & Available Resources & Yes & \multicolumn{1}{|c|}{ No } & No Response & Total \\
\hline $\mathbf{1}$ & Text book & $384(84.4 \%)$ & $38(08.4 \%)$ & $33(7.3 \%)$ & 455 \\
\hline $\mathbf{2}$ & Reference Sources & $219(48.1 \%)$ & $180(39.6 \%)$ & $56(12.3 \%)$ & 455 \\
\hline $\mathbf{3}$ & Back Volumes & $199(43.7 \%)$ & $141(31.0 \%)$ & $115(25.3 \%)$ & 455 \\
\hline $\mathbf{4}$ & Project/Thesis & $116(25.5 \%)$ & $221(48.6 \%)$ & $118(25.9 \%)$ & 455 \\
\hline $\mathbf{5}$ & Online Journals & $43(09.5 \%)$ & $282(62.0 \%)$ & $130(28.6 \%)$ & 455 \\
\hline $\mathbf{6}$ & Databases & $61(13.4 \%)$ & $262(57.6 \%)$ & $132(29.0 \%)$ & 455 \\
\hline $\mathbf{7}$ & Newspaper/Magazine & $287(63.1 \%)$ & $86(18.9 \%)$ & $82(18.0 \%)$ & 455 \\
\hline $\mathbf{8}$ & CD/DVD/VCD & $28(06.2 \%)$ & $290(63.7 \%)$ & $137(30.1 \%)$ & 455 \\
\hline $\mathbf{9}$ & Library Web Links & $72(15.8 \%)$ & $254(55.8 \%)$ & $128(28.1 \%)$ & 455 \\
\hline
\end{tabular}

It is observed from Table 2 that undergraduates use varied sources to meet their information needs. The majority, 384 (84.4\%) use text books, 287 (63.1\%) use newspapers and magazines, and 219 (48.1\%) use reference sources. Out of nine resources, the response on the use of other resources was indicated as Back issues. 199 (43.7\%); Project/Thesis, 116 (25.5\%); Library web links 72 (15.8\%); Databases 61 (13.4\%); Online journals 43 $(9.5 \%)$ and $28(6.2 \%)$ of respondents use CD/DVD/VCD to meet their information needs. Table 2 above, denotes that the use of library databases, web links, online journals and CD/DVD/VCD are less in comparison to books, newspapers/magazines, and reference sources. 


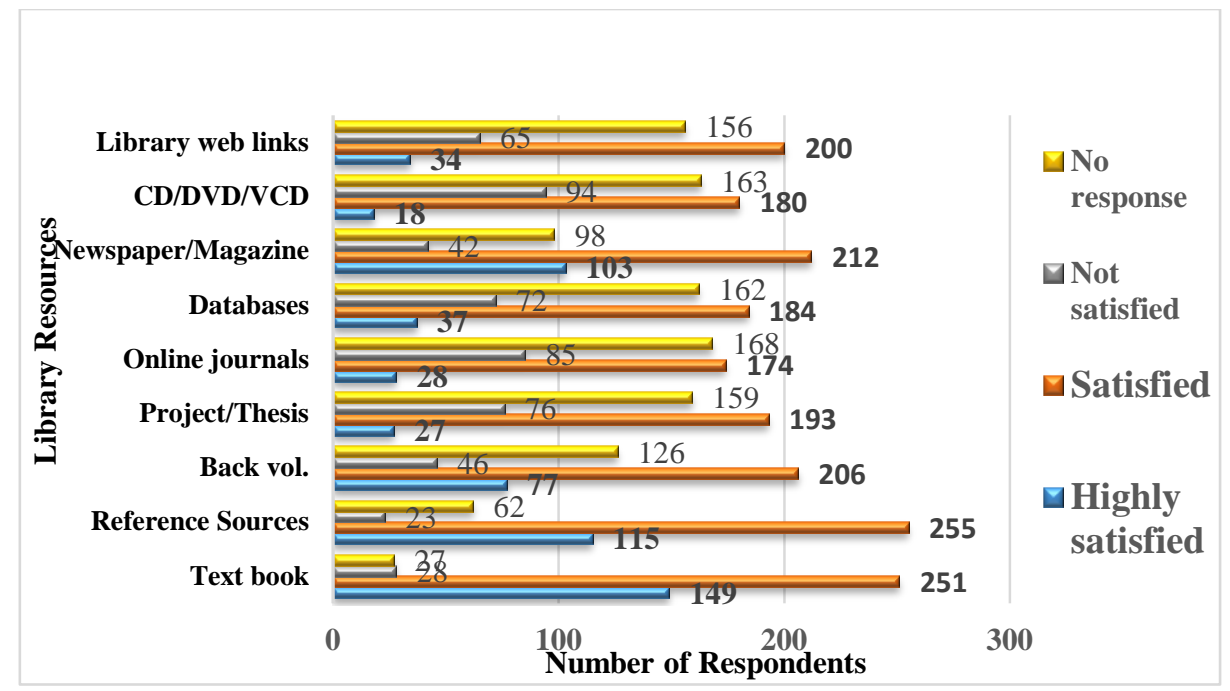

Figure 7: Students' Level of Satisfaction on Library Resources

According to Figure 7, the satisfactory level of the respondents in terms of the collection of publications in the library differs. 149 (32.7\%) are highly satisfied with the text books and $115(25.3 \%)$ are for the collection of reference sources. Out of nine library resources, the level of satisfaction of other library resources was indicated as newspapers/magazines, 103 (22.6\%); Back vol., 77 (16.9\%); databases 37 (8.1\%); library web links 34 (7.5\%); online journals $28(6.2 \%)$ and project/thesis $27(5.9 \%)$ respondents.

\section{Library Services and Facilities}

Table 3 indicates the level of satisfaction by the users with services and facilities offered by the library. It is observed that $69(15.2 \%)$ of the respondents consider the circulation service and reference service as excellent, whereas 68 (14.9\%)respondents consider the reservation of book as an excellent service. $48(10.5 \%)$ respondents regarded the display of new arrivals as excellent. $47(10.3 \%)$ respondents considered the renewal of book as excellent; 43 (9.5\%), photocopying service; 34 (7.5\%), overnight issue, 30 (6.6\%), orientation programme and e-resources retrieval facility; 28 (6.2\%), OPAC/Web OPAC and online library services. Further, findings reveal that $58(12.7 \%)$ respondents are not aware of the online library services followed by $53(11.6 \%)$, overnight issue and OPAC/Web OPAC; $43(9.5 \%)$, eresource retrieval facility. This indicates that even though the library staff conducted a user awareness program at the inception of each degree 
program, it should be conducted at regular intervals throughout each academic year in order to keep reminding library services and facilities. Further, as for the dissatisfaction aspect of the services, it is noted that 117 (25.7\%) of the respondents are dissatisfied with the photocopying service; 91 (20\%) with the display of new arrivals; $76(16.7 \%)$ with the online library services; $72(15.8 \%)$ with the e-resource retrieval facility and $64(14.1 \%)$ with the OPAC/Web OPAC. Hence, the library should pay more attention to develop all above services in order to improve its performance.

Table 3: Students' Level of Satisfaction with Library Services

\begin{tabular}{|c|c|c|c|c|c|c|c|c|}
\hline$\sum_{\sim}^{0}$ & 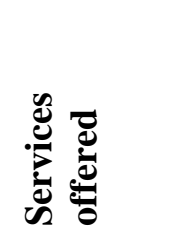 & 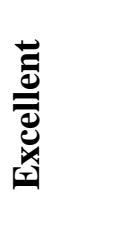 & تُ & 䒕 & 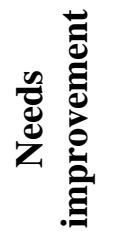 & 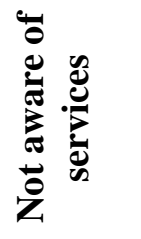 & 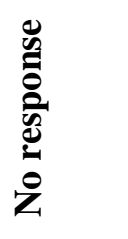 & हुँ \\
\hline 1 & Circulation & $\begin{array}{r}69 \\
(15.2 \%)\end{array}$ & $\begin{array}{r}217 \\
(47.7 \%)\end{array}$ & $\begin{array}{r}65 \\
(14.3 \%)\end{array}$ & $\begin{array}{r}29 \\
(6.4 \%)\end{array}$ & $\begin{array}{r}29 \\
(6.4 \%)\end{array}$ & $\begin{array}{r}46 \\
(10.1 \%)\end{array}$ & 455 \\
\hline 2 & OPAC & $\begin{array}{r}28 \\
(6.2 \%)\end{array}$ & $\begin{array}{r}140 \\
(30.8 \%)\end{array}$ & $\begin{array}{r}108 \\
(23.7 \%)\end{array}$ & $\begin{array}{r}64 \\
(14.1 \%)\end{array}$ & $\begin{array}{r}53 \\
(11.6 \%)\end{array}$ & $\begin{array}{r}62 \\
(13.6 \%)\end{array}$ & 455 \\
\hline 3 & $\begin{array}{l}\text { Orientation } \\
\text { programme } \\
\text { for students }\end{array}$ & $\begin{array}{r}30 \\
(6.6 \%)\end{array}$ & $\begin{array}{r}179 \\
(39.3 \%)\end{array}$ & $\begin{array}{r}109 \\
(24.0 \%)\end{array}$ & $\begin{array}{r}48 \\
(10.5 \%)\end{array}$ & $\begin{array}{r}38 \\
(8.4 \%)\end{array}$ & $\begin{array}{r}51 \\
(11.2 \%)\end{array}$ & 455 \\
\hline 4 & $\begin{array}{l}\text { Retrieval of } \\
\text { E- } \\
\text { Resources }\end{array}$ & $\begin{array}{r}30 \\
(6.6 \%)\end{array}$ & $\begin{array}{r}151 \\
(33.2 \%)\end{array}$ & $\begin{array}{r}100 \\
(22.0 \%)\end{array}$ & $\begin{array}{r}72 \\
(15.8 \%)\end{array}$ & $\begin{array}{r}43 \\
(9.5 \%)\end{array}$ & $\begin{array}{r}59 \\
(13 \%)\end{array}$ & 455 \\
\hline 5 & $\begin{array}{l}\text { Reference/ } \\
\text { Informatio } \\
\text { n Service }\end{array}$ & $\begin{array}{r}69 \\
(15.2 \%)\end{array}$ & $\begin{array}{r}193 \\
(42.4 \%)\end{array}$ & $\begin{array}{r}86 \\
(18.9 \%)\end{array}$ & $\begin{array}{r}32 \\
(7 \%)\end{array}$ & $\begin{array}{r}24 \\
(5.3 \%)\end{array}$ & $\begin{array}{r}51 \\
(11.2 \%)\end{array}$ & 455 \\
\hline 6 & $\begin{array}{l}\text { Reservatio } \\
\mathrm{n} \text { of Books }\end{array}$ & $\begin{array}{r}68 \\
(14.9 \%)\end{array}$ & $\begin{array}{r}179 \\
(39.3 \%)\end{array}$ & $\begin{array}{r}93 \\
(20.4 \%)\end{array}$ & $\begin{array}{r}28 \\
(6.2 \%)\end{array}$ & $\begin{array}{r}26 \\
(5.7 \%)\end{array}$ & $\begin{array}{r}61 \\
(13.4 \%)\end{array}$ & 455 \\
\hline 7 & $\begin{array}{l}\text { Photocopyi } \\
\text { ng Service }\end{array}$ & $\begin{array}{r}43 \\
(9.5 \%)\end{array}$ & $\begin{array}{r}160 \\
(35.2 \%)\end{array}$ & $\begin{array}{r}80 \\
(17.6 \%)\end{array}$ & $\begin{array}{r}117 \\
(25.7 \%)\end{array}$ & $\begin{array}{r}15 \\
(3.3 \%)\end{array}$ & $\begin{array}{r}40 \\
(8.8 \%)\end{array}$ & 455 \\
\hline 8 & $\begin{array}{l}\text { Overnight } \\
\text { issue }\end{array}$ & $\begin{array}{r}34 \\
(7.5 \%)\end{array}$ & $\begin{array}{r}164 \\
(36 \%)\end{array}$ & $\begin{array}{r}85 \\
(18.7 \%)\end{array}$ & $\begin{array}{r}53 \\
(11.6 \%)\end{array}$ & $\begin{array}{r}53 \\
(11.6 \%)\end{array}$ & $\begin{array}{r}66 \\
(14.5 \%)\end{array}$ & 455 \\
\hline 9 & $\begin{array}{l}\text { Renewal of } \\
\text { Books }\end{array}$ & $\begin{array}{r}47 \\
(10.3 \%)\end{array}$ & $\begin{array}{r}172 \\
(37.8 \%)\end{array}$ & $\begin{array}{r}95 \\
(20.9 \%)\end{array}$ & $\begin{array}{r}57 \\
(12.5 \%)\end{array}$ & $\begin{array}{r}25 \\
(5.5 \%)\end{array}$ & $\begin{array}{r}59 \\
(13 \%)\end{array}$ & 455 \\
\hline 10 & $\begin{array}{l}\text { Display of } \\
\text { New } \\
\text { Arrivals }\end{array}$ & $\begin{array}{r}48 \\
(10.5 \%)\end{array}$ & $\begin{array}{r}143 \\
(31.4 \%)\end{array}$ & $\begin{array}{r}90 \\
(19.8 \%)\end{array}$ & $\begin{array}{r}91 \\
(20 \%)\end{array}$ & $\begin{array}{r}31 \\
(6.8 \%)\end{array}$ & $\begin{array}{r}52 \\
(11.4 \%)\end{array}$ & 455 \\
\hline 11 & $\begin{array}{l}\text { Online } \\
\text { Library } \\
\text { Services }\end{array}$ & $\begin{array}{r}28 \\
(6.2 \%)\end{array}$ & $\begin{array}{r}132 \\
(29 \%)\end{array}$ & $\begin{array}{r}99 \\
(21.8 \%)\end{array}$ & $\begin{array}{r}76 \\
(16.7 \%)\end{array}$ & $\begin{array}{r}58 \\
(12.7 \%)\end{array}$ & $\begin{array}{r}62 \\
(13.6 \%)\end{array}$ & 455 \\
\hline
\end{tabular}




\section{Conclusion}

Based on the findings of this study, it is evident that undergraduates are satisfied with the overall library resources, services, and facilities. However, there is a requirement for improvement in the services provided by the library. Further, the study found that library resources and services are not being fully used by undergraduates. This could be either because they are not aware of the resources and services or do not consider them as important for their studies. In addition, the study revealed that less than half of the total respondents visit the library regularly to access past papers which is the main purpose of visiting the library. According to the study, it is identified that the printed books are still taking a predominant place in the library to meet students' information needs and undergraduates are highly satisfied with the collection of textbooks available in the library. This study exposed that printed books are still at the leading place in the library to meet students' information requirement and they are highly satisfied with the collection of textbooks available in the library. Respondents are highly satisfied with the performance of the reference service, circulation service and online reservation of book service. However, the study reveals that a considerable amount of respondents are not aware of some of the services provided by the library, including OPAC/Web OPAC service, online library services, and eresource retrieval facility. Therefore, the library has a vital role to play in advertising library services and emphasizing that the library provides a quality service for its users.

\section{Recommendations}

Based on the findings of the survey, the following recommendations are made;

- Through comprehensive information literacy programs, the library should promote awareness on the use and availability of electronic resources because most of the undergraduates depend on few library resources and services.

- In order to increase the library usage by undergraduates, rather than allocating periods for library free time should be provided by the faculties by having a comprehensive discussion with library staff. 
- Rather than being system centered, the library must be more user centered. For that, the library should conduct user satisfaction studies at regular intervals.

- Librarians should develop an information marketing strategy that should re-examine the needs of the current users and design programs that would enable the administration to identify the information needs of the users. Further, administration of the university should re-examine the human resources development program for the library staff, because it is believed that it would require a special caliber of personnel saturated with identifiable qualities and skills gained through appropriate training programs.

\section{References}

Adeniran, P. (2011). User satisfaction with academic libraries services: Academic staff and students perspectives. Nige International Journal of Library and Information Science, 3(10), 209-216. Retrieved from http://www.academicjournals.org/article/article1379677117_Adenir an.pdf

Ajayi, K (1993). Library and information services for educational development in Nigeria. Lagos Librarian, 14 (2), 29-41.

Ajibero, M. I. (1998). User expectation of Nigerian University library services in the 21st Century. CULNU Proceedings of Ibadan and Ekpoma seminars, 1992 \& 1994, Nigeria

Chandrasekar, K. \& Murugathas, K., (2013). An assessment of user satisfaction on library services: a case study of undergraduate Biology students at the University of Jaffna. Journal of the University Librarians Association of Sri Lanka. 16(1), 34-45. doi: http://doi.org/10.4038/jula.v16i1.5196

Doris, O, Omokoje, A. \& Bamidele, I.A. (2013). Assessing service effectiveness and satisfaction with library services at Babcock 
University , Nigeria. Information Knowledge Management, 3(9), 84$91 . \quad$ Retrieved from http://www.iiste.org/Journals/index.php/IKM/article/view/7519

Goje, L. A. (1995). The library: An indispensable aid to successful research in education. In Research framework for teacher education in Africa. Edited By Lassa, P. N. National Commission For Colleges Of Education.

Gunasekera, C. (2010). Students Usage of an academic Library: a user survey conducted at the Main Library University of Peradeniya. Journal of the University Librarians Association of Sri Lanka, 14 (1), 43-60.

Leckie, G. J., \& Fullerton, A. (1999). Information literacy in science and engineering undergraduate education: Faculty attitudes and pedagogical practices. College and Research Libraries, 60(1), 9-29.

Majid, S. \& Ai, T. T. (2002). Usage of information resources by computer engineering students: A case study of Nanyang Technological University, Singapore. Online Information Review, 26 (5), 318-325.

Olanlokum S. O. (1982). Attitudes of Nigerian university students toward library sue and services. Lagos Librarian, 10(2), 106-123.

Omehia, A. E., Obi, B. B. \& Itohowo, H. (2008). Student characteristics and use of library services in the University of Uyo. Library Philosophy and Practice (e-journal), paper 173. Retrieved from http://digitalcommons.unl.edu/libphilprac/173

Onuoha, U. D, Omokoje, A., \& Bamidele, I. A. (2013). Assessing service effectiveness and satisfaction with library services at Babcock University, Nigeria. Information and Knowledge Management, 3(9), 84-91.Retrieved from http://www.iiste.org/Journals/index.php/IKM/article/view/7519 
Patrick, I. O, Aghojare, B, \& Ferdinand, O.A. (2015). Assess users' satisfaction on academic library performance: a study, International Journal of Academic Research and Reflection, 3(5), 67. Retrieved from http://www.idpublications.org/wpcontent/uploads/2015/05/Abstract-ASSESS-USERS\%E2\%80\%99SATISFACTION-ON-ACADEMIC-LIBRARY-PERFORMANCEA-STUDY.pdf

Sahak, M. D. B., \& Saad, M. S. M. (2011). A Survey on the use of Library Resources, Services and Facilities: A Case Study at the Faculty of Medicine and Health Sciences, University Putra Malaysia. Journal of Information and Knowledge Management, 1(1), 127-139. Retrieved from http://www.geocities.ws/saasfim/article\%209.pdf

Saikia, M., \& Gohain, A. (2013). Use and user's satisfaction in library resources and services A study in Tezpur University (India). International journal of Library and Information Science, 5 (6), 167175

Seneviratne, D., (2006). Measuring user satisfaction: a case study at the PGIM Branch Library at Peradeniya. Journal of the University Librarians Association of Sri Lanka. 10, 40-53. doi: http://doi.org/10.4038/jula.v10i0.317

Sharma, A. K. (1988). Educating library users in college libraries. International Library Movement, 10(1), 35- 43

Yusuf, \& Iwu. (2010). Use of Academic Library: A Case Study of Covenant University. Nigeria Chinese Librarianship: an International Electronic Journal, 30. Retrieved from http://www.whiteclouds.com/iclc/cliej/cl30YI.pdf 